\title{
Electrophysiological Effects of Olanzapine, a Novel Atypical Antipsychotic, on A9 and A10 Dopamine Neurons
}

\author{
Marsha E. Stockton, B.S., and Kurt Rasmussen, Ph.D.
}

This study examined the effects of the novel atypical antipsychotic olanzapine (LY170053) on the activity of substantia nigra pars compacta (A9) and ventral tegmental area (A10) dopamine cells in anesthetized rats. Acute administration of olanzapine $(10,20 \mathrm{mg} / \mathrm{kg} \mathrm{sc})$ increased the number of spontaneously active A10, but not A9, dopamine cells. Chronic administration of olanzapine $(10,20 \mathrm{mg} / \mathrm{kg} /$ day $\times 21$ days) decreased the number of spontaneously active A10, but not A9, dopamine cells. Administration of the dopamine

KEY WORDS: Schizophrenia; Olanzapine;

Electrophysiology; Dopamine; Atypical antipsychotics

Schizophrenia is a debilitating disorder of the central nervous system whose symptoms have been divided into two classes: positive symptoms, including hallucinations, delusions, and conceptual disorganization; and negative symptoms, including social withdrawal, blunted affect, and poverty of speech. Traditionally, classical antipsychotics like haloperidol have been used to treat the positive symptoms of schizophrenia. However, classical antipsychotics have much lower efficacy in treating the negative symptoms of schizophrenia and can also cause extrapyramidal motor side effects (EPS), such as tremor and rigidity. Clozapine has been de-

From Lilly Research Laboratories, Indianapolis, IN.

Address correspondence to: Kurt Rasmussen, Ph.D., Lilly Research Laboratories, Eli Lilly and Company, Lilly Corporate Center, Indianapolis, IN 46285.

Received August 17, 1994; revised November 11, 1994; accepted December 7, 1994. agonist apomorphine reversed the effects of chronic olanzapine on A10 cells, indicating a possible depolarization-inactivation mechanism. In conclusion, olanzapine has selective effects on A10 versus A9 dopamine cells following acute and chronic administration. These effects of olanzapine on dopamine cells are similar to the effects observed with clozapine and may play an important role in the atypical antipsychotic profile of olanzapine. INeuropsychopharmacology 14:97-104, 1996]

scribed as an atypical antipsychotic because it is effective in the treatment of both positive and negative symptoms of schizophrenia and has a low EPS liability (Claghorn et al. 1987; Juul Povlsen et al. 1985). Clozapine also has superior efficacy compared to classical antipsychotics in treating positive and negative symptoms in treatment-responsive (Claghorn et al. 1987) and treatment-refractory (Kane et al. 1988; Meltzer et al. 1989; Miller et al. 1994) schizophrenic patients. In addition, clozapine has been shown to improve cognitive function in treatment-refractory schizophrenic patients (Hagger et al. 1993). The use of clozapine, however, has been severely limited by the occurrence of agranulocytosis (a potentially fatal condition marked by depression of the granulocyte-producing bone marrow) in a small percentage (1-3\%) of the patient population (De la Chapelle et al. 1977; Griffith and Saameli 1975; Lieberman et al. 1988).

One proposal for the etiology of schizophrenia is the dopamine hypothesis. It postulates that hyperactivity of the brain's dopamine system results in schizophrenic symptoms (see Losonczy et al. 1987 for review), although modifications of this hypothesis have recently 
been proposed (Davis et al. 1991; Deutch 1993; Grace 1991; Joyce 1993; Weinberger 1987). The dopamine hypothesis is supported in part by studies demonstrating that antipsychotic drugs have dopamine antagonist properties in vitro (Creese et al. 1976; Malmberg et al. 1993; Seeman et al. 1975) and in vivo (Farde et al. 1992; Nordstrom et al. 1993; see Seeman 1992, 1993 for review). However, it has recently been shown that many atypical antipsychotics show high in vivo affinity for 5- $\mathrm{HT}_{2 \mathrm{~A}}$ receptors but do not show appreciable in vivo affinity for $\mathrm{D}_{2}$ receptors (Matsubara et al. 1993; Stockmeier et al. 1993). Additional support for the dopamine hypothesis has come from electrophysiological studies which have shown that chronic treatment with classical antipsychotics (e.g., haloperidol) decreased the number of spontaneously active dopamine cells in both the ventral tegmental area (A10, which project primarily to the limbic and cortical regions) and the substantia nigra pars compacta (A9, which project primarily to the striatum) (Bunney and Grace 1978; Chiodo and Bunney 1983; White and Wang 1983). In addition, the time course for the decrease in A9 and A10 activity paralleled the time course of the emergence of some of the therapeutic and EPS of these drugs. However, chronic treatment with atypical antipsychotics (e.g., clozapine) selectively decreased the number of spontaneously active A10, but not A9, dopamine cells (Chiodo and Bunney 1983; White and Wang 1983; see Bunney 1992 for review). Therefore, since atypical antipsychotics have a greatly reduced propensity for producing EPS, and because the time course required to decrease dopamine neuronal activity closely parallels the onset of the clinical effects of these drugs, it has been hypothesized that the decrease in A10 activity may underlie the therapeutic effects of antipsychotics, while the decrease in A9 activity may underlie the EPS associated with classical neuroleptic treatment.

Olanzapine, a thienobenzodiazepine [LY170053, 2-methyl-4-(4-methyl-1-piperazinyl)-10H-thieno[2,3$\mathrm{B}][1,5]$ benzodiazepine)] (Figure 1 ) is a novel atypical antipsychotic. Olanzapine has a binding profile similar to that of clozapine; each displays high affinity for $\mathrm{D}_{1}, \mathrm{D}_{2}$, and $\mathrm{D}_{4}$ dopamine, serotonin 5- $\mathrm{HT}_{2 \mathrm{~A}}$ (formerly $5-\mathrm{HT}_{2}$ ), 5- $\mathrm{HT}_{2 \mathrm{C}}$ (formerly 5- $\mathrm{HT}_{1 \mathrm{C}}$ ), 5- $\mathrm{HT}_{3}$, and $5-\mathrm{HT}_{6}$, $\alpha_{1}$-adrenergic, histamine ${ }_{1}$, and muscarinic receptors (Bymaster et al. 1996; Roth et al. 1994). The effects of olanzapine in several behavioral tests (including conditioned avoidance responding, apomorphine induced climbing, 5-HTP-induced head twitch, punished responding and drug discrimination studies-(Moore et al. 1992) and in neuroendocrine assays (Fuller and Snoddy 1992) suggest that olanzapine and clozapine have similar pharmacological profiles and might therefore have similar atypical antipsychotic profiles in man. Indeed, in clinical studies of schizophrenic and schizophreniform patients, olanzapine effectively treated both

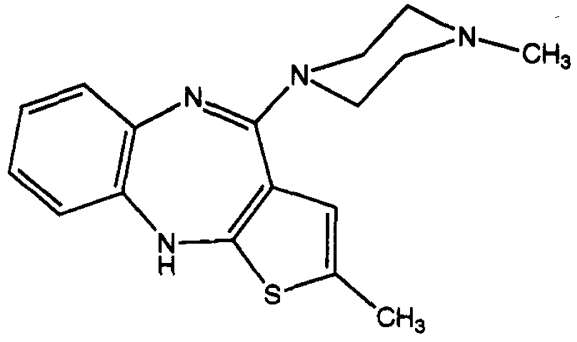

Figure 1. The chemical structure of olanzapine (LY170053), 2-methyl-4-(4-methyl-1-piperazinyl)-10H-thieno[2,3-B][1,5] benzodiazepine.

positive and negative symptoms of schizophrenia and had a low incidence of EPS (Beasley et al. 1996). In order to explore the electrophysiological profile of olanzapine, we examined the effects of acute and chronic administration of olanzapine on A9 and A10 dopamine neuronal activity using extracellular single-unit recording techniques in anesthetized rats. These studies were conducted in accordance with the Guide for the Care and Use of Laboratory Animals.

\section{METHODS}

\section{Electrophysiological Recordings}

Male Sprague-Dawley rats (280-330 g; Charles River) were anesthetized with chloral hydrate $(400 \mathrm{mg} / \mathrm{kg}$ IP); supplemental doses of anesthetic were administered through the lateral tail vein as needed. Body temperature was maintained at $35^{\circ} \mathrm{C}$ by a heating pad (K-Module, American Pharmaseal Co., Valencia, CA). The anesthetized rats were mounted in a stereotaxic apparatus (Kopf Instruments), the skull exposed, and a cisternal drain performed to prevent tissue swelling. A burr hole was made in the skull over the A9 and A10 areas. To construct recording electrodes, single-barrel glass micropipettes (Radnoti, starbore glass) were pulled (Narishige PE-2 vertical puller); the resulting fine tips broken back and the barrels were backfilled with $2 \mathrm{M} \mathrm{NaCl}$. Electrode impedances were 1.8 to $2.6 \mathrm{M} \Omega$ (in vivo measurements with a Dagan 2400 preamplifier utilizing a $2-\mathrm{Hz}, 100-n$ A peak-to-peak square wave).

For recording neuronal activity the bandpass filter on the preamplifier was set from 0.3 to $3 \mathrm{kHz}$. The tip of the recording electrode was lowered to the dorsal border of either A9 or A10 and then advanced, using a micropositioning device (Burleigh, Inchworm Motor Controller), in $5-\mu \mathrm{m}$ increments through the nucleus. The electrode was passed through nine tracks (each track was separated by $0.2 \mathrm{~mm}$ ) in a stereotaxically defined block of tissue (5.0-5.4 mm posterior, 2.0-2.4 $\mathrm{mm}$ lateral to bregma and $6.0-8.5 \mathrm{~mm}$ ventral to the cortical surface for A9; and 5.0-5.4 mm posterior and $0.5-0.9 \mathrm{~mm}$ lateral to bregma and $6.0-8.5 \mathrm{~mm}$ ventral to the cortical surface for $\mathrm{A} 10$ ), and the number of spon- 
taneously active dopamine cells was counted. The electrode tracks were made in a preset sequence that was kept constant from animal to animal. For animals acutely treated, proper anatomical positioning of the recording electrode was ensured by scoring three control tracks prior to drug treatment. Six additional tracks were recorded 1 hour following SC injection of olanzapine or vehicle. Only one area, either A9 or A10, was recorded in each acutely treated animal. For chronically treated animals, nine tracks were scored in both $\mathrm{A} 9$ and A10; the first site examined (either A9 or A10) was alternated to control for order effects. Spontaneously active dopamine cells were recorded as previously reported (Chiodo and Bunney 1983; Rasmussen et al. 1991a, b; White and Wang 1983). Briefly, cells were considered dopaminergic if they possessed the following characteristics: (1) action potential duration of 2.5 to 4.5 ms; (2) triphasic waveform containing a notch in the initial rising phase of the first positive peak; and (3) slow, slightly irregular firing pattern, with a rate of 2 to $10 \mathrm{~Hz}$. Previously, these characteristics have been demonstrated to be shown only by dopaminergic neurons (Bunney et al. 1973). A digital oscilloscope (Gould 1604) was used to analyze the spike waveforms; 8 waveforms were captured, averaged, and then displayed for analysis. The firing rate of each cell was monitored for 1 to 2 minutes to ensure that the cells had not been mechanically excited.

\section{Drug Treatment}

Olanzapine was dissolved in a minimal amount of $1 \mathrm{~N}$ $\mathrm{HCl}$; the solution was $\mathrm{pH}$-adjusted to $5.1-5.5$ with $0.1 \mathrm{~N}$ $\mathrm{NaOH}$ and brought to volume with $\mathrm{dH}_{2} \mathrm{O}$. The vehicle was $\mathrm{dH}_{2} \mathrm{O}, \mathrm{pH}$-adjusted to $5.1-5.5$ with $0.1 \mathrm{~N} \mathrm{HCl}$.

For acute treatment olanzapine or the vehicle was administered by a single SC injection. For chronic treatment, a constant rate of drug delivery was maintained by SC implantation of Alzet 2ML4 osmotic minipumps (Alza, Palo Alto, CA) containing olanzapine or the vehicle into $150-g$ male Sprague-Dawley rats. Because of solubility limitations, animals receiving $10 \mathrm{mg} / \mathrm{kg} /$ day olanzapine had one pump implanted, while those receiving $20 \mathrm{mg} / \mathrm{kg} /$ day olanzapine had two pumps implanted. Implant surgeries were carried out while the animals were lightly anesthetized with halothane. Electrophysiological recordings were performed 21 days postimplantation; pumps were not removed prior to recording. The volume of fluid in the pump was measured before and after treatment to verify that the proper amount of olanzapine was delivered.

\section{Data Analysis}

Results were analyzed using either paired $t$-tests, with each animal serving as its own control, or one-way anal-

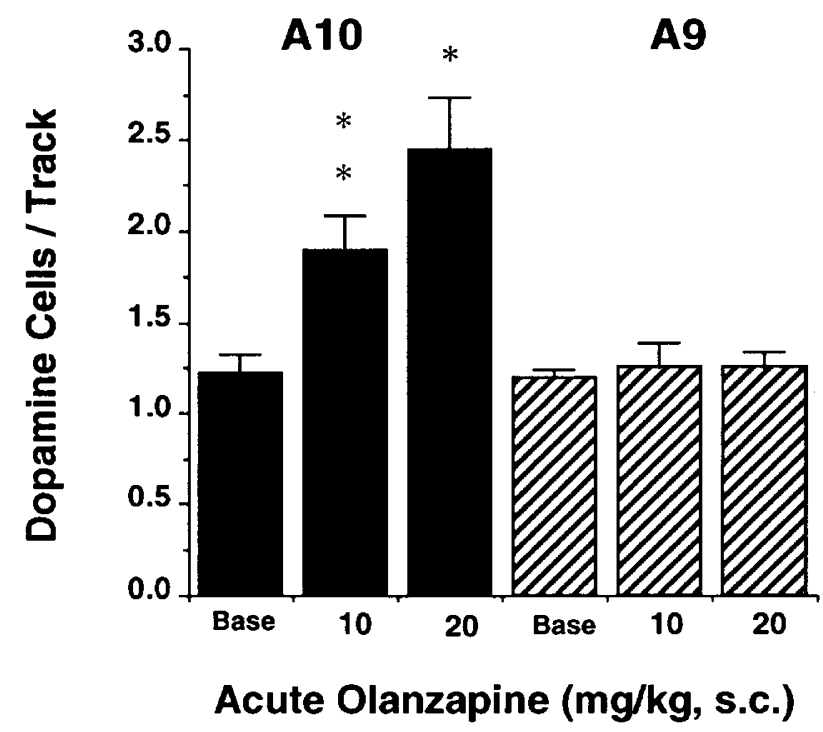

Figure 2. The number of spontaneously active A10 (solid bars) and A9 (striped bars) dopamine cells encountered 1 hour after a single $\mathrm{SC}$ administration of olanzapine (mean $\pm \mathrm{SE}, n=$ 4-6). Asterisks indicate values that are significantly different (paired $t$-tests) from baseline (base; average number of dopamine cells encountered prior to drug administration; see Methods): ${ }^{*} p<.05 ;{ }^{\star *} p<.01$.

ysis of variance (ANOVA) coupled with Fisher PLSD tests.

\section{RESULTS}

Acute administration of olanzapine $(10$ and $20 \mathrm{mg} / \mathrm{kg}$ SC) significantly increased ( $p<.01, p<.05$, respectively) the number of spontaneously active A10 dopamine cells ( $n=4$ per group), but it did not change the number of spontaneously active A9 dopamine cells ( $n=4$ and 6 per group, respectively) (Figure 2). Following acute administration, the lower dose of olanzapine $(10 \mathrm{mg} / \mathrm{kg}$ $\mathrm{SC}$ ) significantly decreased the mean firing rate of spontaneously active A10 dopamine cells $(n=32)$, while the higher dose of olanzapine $(20 \mathrm{mg} / \mathrm{kg} \mathrm{SC})$ did not change the mean firing rate of A10 dopamine cells $(n=22)$ (Figure 3). Neither dose of olanzapine (10 or $20 \mathrm{mg} / \mathrm{kg}$ ) had any significant effect on the mean firing rate of $A 9$ dopamine cells ( $n=17$ and 27 per group, respectively) (Figure 3).

Following chronic administration (10 and $20 \mathrm{mg} /$ $\mathrm{kg} /$ day for 21 days), olanzapine dose-dependently decreased the number of spontaneously active A10 dopamine cells ( $n=5$ and 14 animals per group, respectively) compared to vehicle treatment $(n=5)$ and increased the number of spontaneously active A9 dopamine cells only at the higher $(20-\mathrm{mg} / \mathrm{kg} /$ day SC) dose $(n=24$ animals) compared to vehicle treatment $(n=7)$ (Figure 4). Chronic administration of olanzapine (10 and 20 


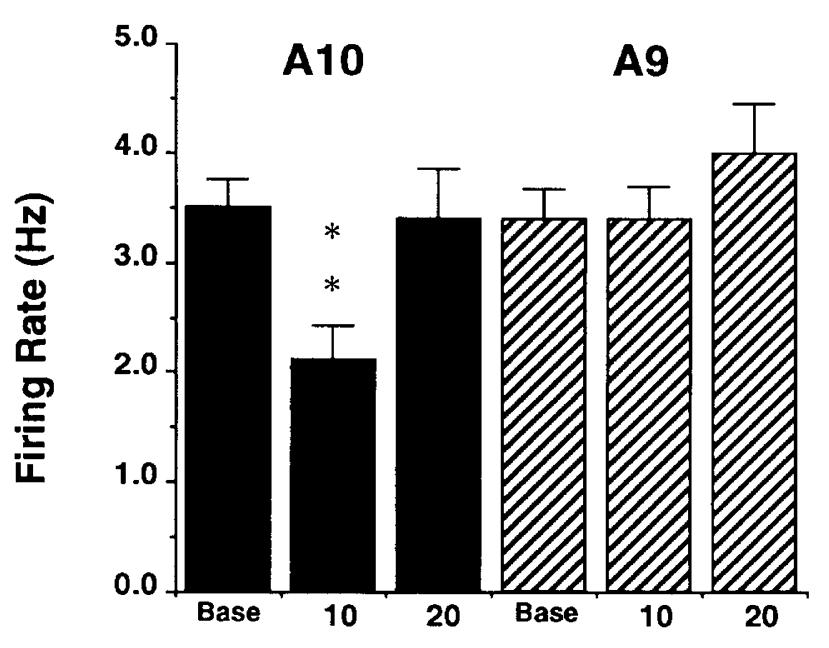

Acute Olanzapine ( $\mathrm{mg} / \mathrm{kg}$, s.c.)

Figure 3. Firing rate ( $\mathrm{Hz}$; number of cell-firings/s) of spontaneously active A10 (solid bars) and A9 (striped bars) dopamine cells 1 hour after a single SC administration of olanzapine (mean $\pm \mathrm{SE}, n=17-48$ ). Asterisks indicate values that are significantly different (ANOVA) from baseline (base; average furing rate of spontaneously active A9 or A10 dopamine cells prior to drug administration): ${ }^{\star \star} p<.01$.

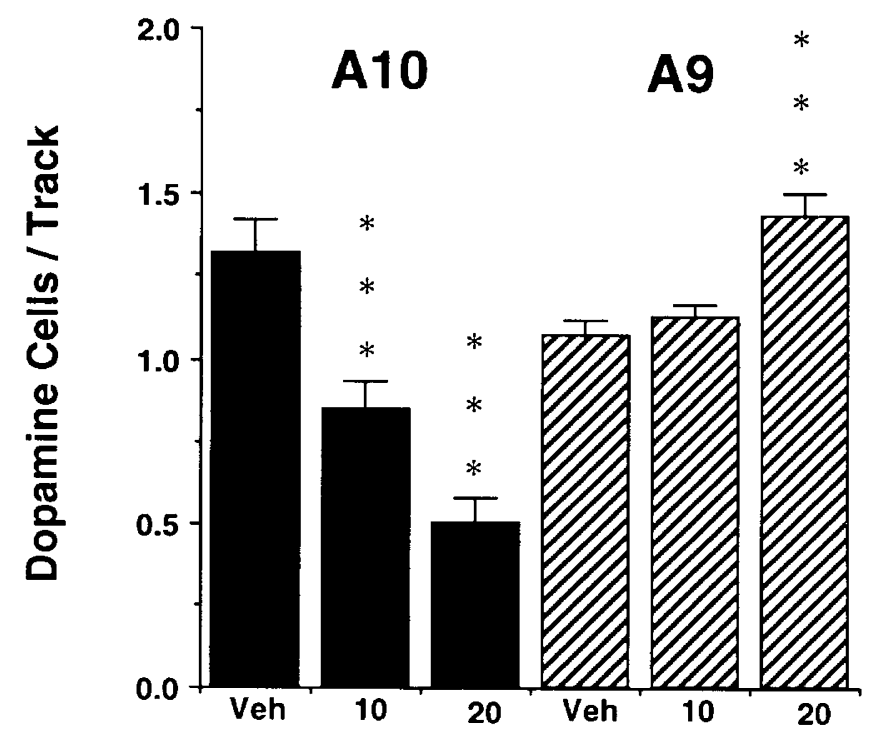

Chronic Olanzapine (mg/kg/day, s.c.)

Figure 4. The number of spontaneously active A10 (solid bars) and A9 (striped bars) dopamine cells following chronic administration (21 days via osmotic minipump) of olanzapine or vehicle $(V e h)$ (mean \pm SE, $n=5-9)$. Asterisks indicate values that are significantly different (ANOVA) from vehicle controls: ${ }^{\star \star \star} p<.001$. $\mathrm{mg} / \mathrm{kg} /$ day SC) did not significantly increase the mean fring rate of spontaneously active $\mathrm{A} 9(n=47$ and 39 , respectively) or $\mathrm{A} 10$ ( $n=38$ and 15 , respectively) dopamine cells compared to vehicle treatment $(n=48$ for A9 and 43 for A10) (Figure 5).

Administration of apomorphine (10 and $63 \mu \mathrm{g} / \mathrm{kg}$ IV) dose-dependently reversed the decrease in the number of spontaneously active A10 dopamine cells encountered following chronic administration of olanzapine $(20 \mathrm{mg} / \mathrm{kg} /$ day). These same doses of apomorphine decreased the number of spontaneously active A9 dopamine cells encountered following chronic administration of olanzapine $(20 \mathrm{mg} / \mathrm{kg} /$ day $) ;(n=3$ and 4 animals per group, respectively) (Figure 6).

\section{DISCUSSION}

Acute administration of olanzapine $(10,20 \mathrm{mg} / \mathrm{kg} \mathrm{SC})$ produced an increase in the number of spontaneously active A10 dopamine cells but no change in the number of spontaneously active A9 dopamine cells (Figure 2). Acute administration of clozapine and other atypical antipsychotics has also been reported to selectively increase the number of spontaneously active A10 (relative to A9) dopamine cells (Goldstein et al. 1993; White and Wang 1983; but see Chiodo and Bunney 1983). Acute administration of antipsychotics has been shown to produce this increase in the number of spontaneously active dopamine cells by activating a subpopulation of dopamine cells that were previously inactive due to

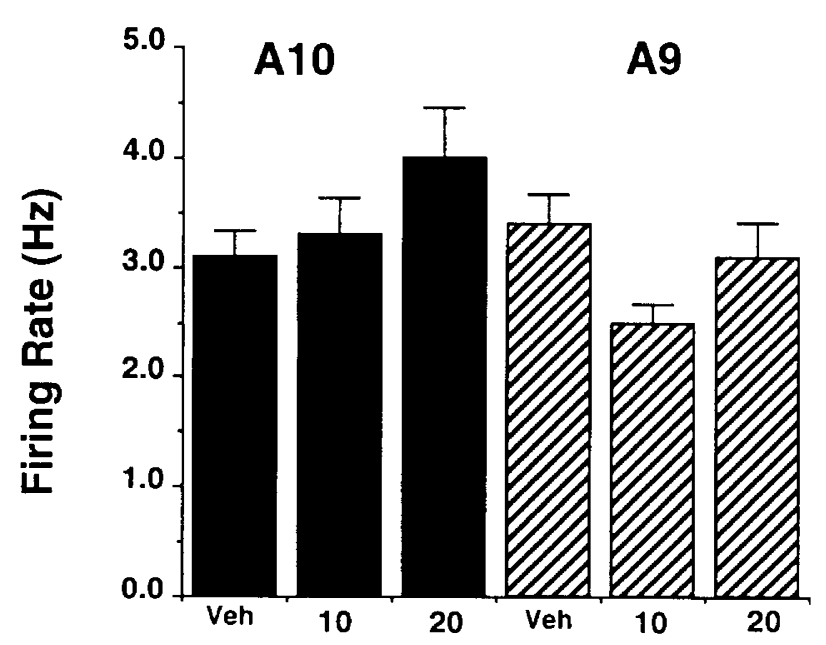

\section{Chronic Olanzapine (mg/kg/day, s.c.)}

Figure 5. Firing rate (Hz; number of cell-firings/s) of spontaneously active A10 (solid bars) and A9 (striped bars) dopamine cells following chronic administration (21 days via osmotic minipump) of olanzapine or vehicle (Veh) (mean $\pm S E$, $n=15-48)$. 


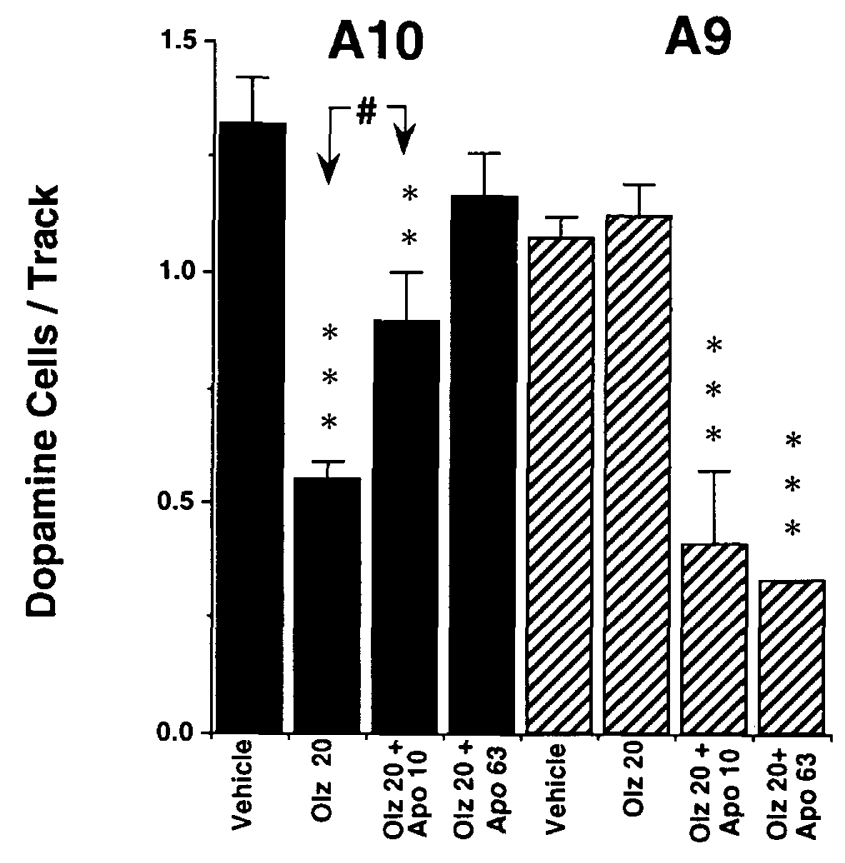

\section{Treatment}

Figure 6. Effect of administration of apomorphine (Apo; 10 or $63 \mu \mathrm{g} / \mathrm{kg} \mathrm{IV)} \mathrm{on} \mathrm{the} \mathrm{number} \mathrm{of} \mathrm{spontaneously} \mathrm{active} \mathrm{A10}$ (solid bars) and A9 (striped bars) dopamine cells following chronic administration (21 days via osmotic minipump) of either olanzapine $(\mathrm{Olz} ; 20 \mathrm{mg} / \mathrm{kg} /$ day) or vehicle (Veh) (mean $\pm \mathrm{SE}, n=3-7$ ). Asterisks indicate values that are significantly different (ANOVA) from vehicle controls: ${ }^{\star \star} p<$ $.01 ;^{* \star \star} p<.001$. Pound-sign indicates values that are significantly different between dose groups: ${ }^{\#} p<.05$.

hyperpolarization (Bunney and Grace 1978; Chiodo and Bunney 1983). A selective increase in the number of spontaneously active A10 dopamine cells following acute administration of antipsychotics has been hypothesized to underlie the subsequent selective decrease in the number of spontaneously active A10 dopamine cells seen following chronic administration of antipsychotics via depolarization inactivation - see later (Chiodo and Bunney 1983; Goldstein et al. 1993). Furthermore, the selective increase in the number of spontaneously active A10 dopamine cells seen following acute administration of antipsychotics has been hypothesized to be predictive of atypical antipsychotic activity in man (Bunney and Grace 1978; Chiodo and Bunney 1983; Goldstein et al. 1993). In preliminary clinical trials olanzapine was efficacious in treating both the positive and negative symptoms of schizophrenia and had a low incidence of EPS (Beasley et al. 1996). Thus, clinical results obtained with olanzapine support the predictive validity of the selective increase in the number of spontaneously active A10 dopamine cells following acute administration as a preclinical test for atypical antipsychotic effects in man.

Although acute administration of olanzapine selec- tively increased the number of spontaneously active A10 dopamine cells, only modest changes in the mean furing rate of the spontaneously active $\mathrm{A} 9$ and $\mathrm{A} 10$ dopamine cells were observed. In A10, $20 \mathrm{mg} / \mathrm{kg}$ olanzapine did not change the mean firing rate of the dopamine cells encountered. However, a lower dose $(10 \mathrm{mg} / \mathrm{kg})$ resulted in a significant decrease in the mean firing rate of the A10 dopamine cells (Figure 3). In A9, the firing rate of the spontaneously active dopamine neurons was not different from control following either dose of olanzapine (Figure 3). Previous studies report that acute administration of atypical antipsychotics did not signifcantly alter the firing rate of A9 or A10 dopamine cells that were already active prior to drug administration (Bunney and Aghajanian 1974, 1975). Preliminary results from our laboratory also indicate that olanzapine does not significantly alter the firing rate of $\mathrm{A} 9(n=3)$ or A10 $(n=5)$ dopamine cells that are active prior to drug administration. Thus, one possible explanation for the effects of olanzapine on the mean firing rates of A10 dopamine cells is that $10 \mathrm{mg} / \mathrm{kg}$ may be a sufficient dose of olanzapine to cause previously inactive cells to fire, but only at rates below control levels. However, $20 \mathrm{mg} / \mathrm{kg}$ of olanzapine may be enough to induce previously inactive cells to fire at control rates. Single-unit recordings examining the activity of both spontaneously active and inactive (i.e., hyperpolarized) A10 dopamine cells in response to increasing doses of olanzapine would help to test this hypothesis.

Chronic administration of olanzapine resulted in a decrease in the number of spontaneously active A10 dopamine neurons (Figure 4). In A9, chronic administration of $10 \mathrm{mg} / \mathrm{kg}$ olanzapine produced no change in the number of spontaneously active dopamine cells, while chronic administration of $20 \mathrm{mg} / \mathrm{kg}$ produced a significant increase in the number of spontaneously active dopamine cells (Figure 4). These results with olanzapine were similar to those seen following the chronic administration of clozapine and other proposed atypical antipsychotics (Chiodo and Bunney 1983; Skarsfeldt 1988b; White and Wang 1983). This selective decrease of A10 (relative to A9) dopamine activity has been hypothesized to be predictive of atypical antipsychotic activity (Chiodo and Bunney 1983; White and Wang 1983); clinical results obtained with olanzapine (Beasley et al. 1996) support this hypothesis. Following chronic administration of olanzapine, the furing rates of the A9 and A10 dopamine cells encountered were not significantly different from those of vehicle-treated controls. However, in the high-dose group there was a trend toward significantly higher firing rates for A10 dopamine cells. Chronic administration of clozapine has previously been reported to result in increased firing rates of the remaining active A10 dopamine cells (Chiodo and Bunney 1983). Whether higher doses of olanzapine would produce a greater increase in the firing rates of the remaining active $\mathrm{A} 10$ dopamine cells remains to be determined. 
The selective effects of olanzapine in $\mathrm{A} 10$ relative to A9 dopamine cells following both acute and chronic administration could be accounted for by its complex pharmacological profile. Previous reports indicated that compounds which are relatively selective for particular receptor subtypes decreased the number of spontaneously active A9 and/or A10 dopamine cells following chronic administration. For example, following chronic administration, compounds selective for $5-\mathrm{HT}_{3}$ (Minabe et al. 1991; Sorensen et al. 1989), 5- $\mathrm{HT}_{3 / 4}$ (Skarsfeldt 1993), dopamine $\mathrm{D}_{2}$ (Chiodo and Bunney 1983; Skarsfeldt 1993; White and Wang 1983); dopamine $\mathrm{D}_{1} / 5-\mathrm{HT}_{2 \mathrm{~A} / 2 \mathrm{C}}$ (Skarsfeldt 1988a; but see Esposito and Bunney 1988), and CCK-B (Rasmussen et al. 1991b) receptors have been reported to decrease the number of both spontaneously active A9 and A10 dopamine cells. However, compounds selective for 5-HT $2 \mathrm{~A}$ (Palfreyman et al. 1993), 5- $\mathrm{HT}_{2 \mathrm{~A} / 2 \mathrm{C}}$ (Goldstein et al. 1989), 5- $\mathrm{HT}_{2 \mathrm{~A} / 2 \mathrm{~B} / 2 \mathrm{C} / 1 \mathrm{D}}$ (Goldstein and Litwin 1988b), 5- $\mathrm{HT}_{3}$ (Minabe et al. 1992; Prisco et al. 1991; Rasmussen et al. 1991a); dopamine $D_{2}$ (Skarsfeldt 1993; White and Wang 1983), dopamine $D_{1} / 5-H_{2 A} / 2 C$ (Goldstein and Litwin 1988a; Wachtel and White 1992), and sigma/5-HT $1 \mathrm{~A}$ (Watchel and White 1988) receptors have been reported selectively to decrease only the number of spontaneously active A10 dopamine cells. In addition, compounds with affinity for several receptor subtypes also decreased the number of spontaneously active A9 and/or A10 dopamine cells following chronic administration. For example, following chronic administration, haloperidol, chlorpromazine (Chiodo and Bunney 1983; White and Wang 1983) and tefludazine (Skarsfeldt 1988b) have been reported to decrease the number of both spontaneously active $\mathrm{A} 9$ and $\mathrm{A} 10$ dopamine cells, while clozapine (Chiodo and Bunney 1983; Skarsfeldt 1988b, White and Wang 1983), molindone (White and Wang 1983), sertindole (Skarsfeldt 1992), and seroquel (Goldstein et al. 1993) have been reported selectively to decrease only the number of spontaneously active A10 dopamine cells. Olanzapine has a high binding affinity for a variety of dopaminergic $\left(\mathrm{D}_{1}, \mathrm{D}_{2}, \mathrm{D}_{3}\right)$, serotonergic $\left(5-\mathrm{HT}_{2} \mathrm{~A}\right.$, $\left.5-\mathrm{HT}_{2 \mathrm{C}}, 5-\mathrm{HT}_{3}, 5-\mathrm{HT}_{6}\right)$, noradrenergic $\left(\alpha_{1}\right)$, histaminic $\left(\mathrm{H}_{1}\right)$, and muscarinic $\left(\mathrm{m}_{1-5}\right)$ receptors (Roth et al. 1994; Bymaster et al. this issue) and has antagonist properties in vivo at most of these same receptors (Fuller and Snoddy 1992; Moore et al. 1992). Whether activity at any one receptor or a specific combination of these receptors accounts for the selective effects of olanzapine on A10 dopamine cells remains to be determined.

The decreased activity of A9 and A10 dopamine neurons produced by chronic administration of antipsychotic drugs has been postulated to arise from a chronic state of strong depolarization (i.e, depolarization inactivation or depolarization block) (Bunney and Grace 1978; Chiodo and Bunney 1983; see Grace 1992 for review). The depolarization inactivation hypothe- sis is supported in part by studies showing that systemic administration of apomorphine, a dopamine agonist which hyperpolarizes dopamine cells in control animals, reverses the effects of chronic administration of antipsychotic drugs by causing previously nonfiring dopamine cells to become active (Bunney and Grace 1978). In the present study systemic administration of apomorphine dose-dependently reversed the effects of chronic administration of olanzapine on A10 dopamine cells (Figure 6). In contrast, these same doses of apomorphine inhibited the activity of A9 dopamine cells in animals chronically treated with olanzapine. A previous study reported that apomorphine did not decrease the number of spontaneously active A9 dopamine cells in animals chronically treated with clozapine, thioridazine, or d,l-sulpiride (White and Wang 1983). However, another study reported that apomorphine was able to decrease the number of spontaneously active A9 dopamine cells in animals chronically treated with 5-HT 3 antagonist DAU 6215 (Prisco et al. 1991). Whether chronic administration of olanzapine has different effects from clozapine, thioridazine, or d,lsulpiride on A9 dopamine cells remains to be determined. Apomorphine-induced reversal of the effects of chronically administered olanzapine on A10 dopamine cells suggests that olanzapine, similarly to other antipsychotic drugs, affects the activity of A10 dopamine cells through depolarization inactivation. Intracellular recordings and iontophoretic studies using hyperpolarizing and depolarizing agents would help to confirm this hypothesis. Whether depolarization inactivation of dopamine neurons actually occurs in man and, if it does, what role it plays in the therapeutic effects of antipsychotic drugs is not clear (Bunney 1992; Grace 1992; Meltzer 1991; Moghaddam and Bunney 1993). Whatever the ultimate role for depolarization inactivation in the mechanism of action of antipsychotic drugs, the present results support the predictive validity of the selective decrease of A10 dopamine activity, through a depolarization inactivation mechanism, as a preclinical predictor of antipsychotic efficacy and decreased motor side effect liability in man. However, it is important to note that selective inactivation of A10 versus $A 9$ neurons is not a perfect predictor of atypical antipsychotic behavior in man. For example, BMY 14802 selectively inactivates A10 neurons following chronic administration in rats (Wachtel and White 1988) but does not have antipsychotic activity in man (Gewirtz et al. 1994).

In conclusion, olanzapine selectively increased the number of spontaneously active A10 (relative to A9) dopamine cells following acute administration and selectively decreased the number of spontaneously active A10 (relative to A9) dopamine cells following chronic administration. These results are similar to those obtained for clozapine and other proposed atyp- 
ical antipsychotic drugs (Chiodo and Bunney 1983; Skarsfeldt 1988b; White and Wang 1983). Since olanzapine has been demonstrated to have an atypical antipsychotic profile in clinical trials (Beasley et al. in press), these findings support the hypothesis that a decrease in the number of spontaneously active A10 dopamine neurons may play a role in the therapeutic effects of antipsychotic drugs, while a decrease in the number of spontaneously active A9 dopamine neurons may play a role in the motor side effects of antipsychotic drugs.

\section{REFERENCES}

Beasley CM, Tollefson GD, Tran P, Satterlee W, Sanger T, Holman S, HGAD Olanzapine Study Group (1996): Olanzapine versus placebo and haloperidol: Acute phase results of the North American double-blind olanzapine trial. Neuropsychopharmacology 14:111-123

Bymaster FP, Calligaro DO, Falcone JF, Marsh RD, Moore ND, Tye NC, Seeman P, Wong DT (1996): Radioreceptor binding profile of the atypical antipsychotic olanzapine. Neuropsychopharmacology 14:87-96

Bunney BS (1992): Clozapine: A hypothesized mechanism for its unique clinical profile. Br J Psychiatry 160(suppl. 17):17-21

Bunney BS, Aghajanian GK(1974): A comparison of the effects of chlorpromazine, 7-hydroxychlorpromazine and chlorpromazine sulfoxide on the activity of central dopaminergic neurons. Life Sci 15:309-318

Bunney BS, Aghajanian GK (1975): Antipsychotic drugs and central dopaminergic neurons: A model for predicting therapeutic efficacy and incidence of extrapyramidal side effects. In Sudilovsky A, Gershon S, Beer B (eds), Predictability in Psychopharmacology: Preclinical and Clinical Correlations, New York, Raven, pp 225-245

Bunney BS, Grace AA (1978): Acute and chronic haloperidol treatment: Comparison of effects on nigral dopaminergic cell activity. Life Sci 23:1715-1728

Bunney BS, Walters JR, Roth RH, Aghajanian GK (1973): Dopaminergic neurons: Effects of antipsychotic drugs and amphetamine on single cell activity. J Pharm Exp Ther 185:560-571

Chiodo LA, Bunney BS (1983): Typical and atypical neuroleptics: Differential effects of chronic administration on the activity of A9 and A10 midbrain dopaminergic neurons. J Neurosci 3:1607-1619

Claghorn J, Honigfeld G, Abuzzahab FS Sr, Wang R, Steinbock R, Tuason V, Klerman G (1987): The risks and benefits of clozapine versus chlorpromazine. J Psychopharmacol 7:377-384

Creese I, Burt DR, Snyder SH (1976): Dopamine receptor binding predicts clinical and pharmacological potencies of antischizophrenic drugs. Science 192:481-483

Davis KL, Kahn RS, Ko G, Davidson M (1991): Dopamine in schizophrenia: A review and reconceptualization. Am J Psychiatry 148:1474-1486

De la Chapelle A, Kari C, Nurminen M, Hernberg S (1977): Clozapine-induced agranulocytosis. Hum Genet 37:183194
Deutch AY (1993): Prefrontal cortical dopamine systems and the elaboration of functional corticostriatal circuits: Implications for schizophrenia and Parkinson's disease. J Neural Transm [GenSect] 91:197-221

Esposito E, Bunney BS (1988): The effect of acute and chronic treatment with $\mathrm{SCH} 23390$ on the spontaneous activity of midbrain dopamine neurons. Eur J Pharmacol 162: 109-113

Farde L, Nordstrom A-L, Wiesel FA, Pauli S, Halldin C, Sedvall G (1992): Positron emission tomographic analysis of central $D_{1}$ and $D_{2}$ dopamine receptor occupancy in patients treated with classical neuroleptics and clozapine. Arch Gen Psychiatry 49:538-544

Fuller RW, Snoddy HD (1992): Neuroendocrine evidence for antagonism of serotonin and dopamine receptors by olanzapine (LY170053), an antipsychotic drug candidate. Res Comm Chem Path Pharm 77:87-93

Gewirtz GR, Forman JM, Volavka J, Macaluso J, Gribkoff G, Taylor DP, Borison J (1994): BMY 14802, a sigma receptor ligand for the treatment of schizophrenia. Neuropsychopharm 10:37-40

Goldstein JM, and Litwin LC (1988a): Spontaneous activity of A9 and A10 dopamine neurons after acute and chronic administration of the selective dopamine D-1 receptor antagonist SCH23390. Eur J Pharmacol 155:175-180

Goldstein JM, Litwin LC (1988b): Antipsychotic-like activity of ritanserin following chronic treatment in rats. FASEB 2:A1404

Goldstein JM, Litwin LC, Sutton EB, Malick JB (1989): Effects of ICI 169,369 , a selective serotonin 2 antagonist, in electrophysiological tests predictive of anti-psychotic activity. J Pharmacol Exp Ther 249:673-680

Goldstein JM, Litwin CL, Sutton EB, Malick JB (1993): Seroquel: Electrophysiological profile of a potential atypical antipsychotic. Psychopharmacology 112:293-298

Grace AA (1919): Phasic versus tonic release and the modulation of dopamine system responsivity: A hypothesis for the etiology of schizophrenia. Neurosci 41:1-24

Grace AA (1992): The depolarization block hypothesis of neuroleptic action: Implications for the etiology and treatment of schizophrenia. J Neural Transm 36:91-131

Griffith RW, Saameli K (1975): Clozapine and agranulocytosis. Lancet 2:657

Hagger C, Buckley P, Kenny JT, Friedman L, Ubogy D, Meltzer HY (1993): Improvement in cognitive functions and psychiatric symptoms in treatment-refractory schizophrenic patients receiving clozapine. Biol Psychiatry 34: 702-712

Joyce JN (1993): The dopamine hypothesis of schizophrenia: Limbic interactions with serotonin and norepinephrine. Psychopharmacology 112:S16-S34

Juul Povlsen U, Noring U, Fog R, Gerlach J (1985): Tolerability and therapeutic effect of clozapine: A retrospective investigation of 216 patients treated with clozapine for up to 12 years. Acta Psychiatr Scand 71:176-185

Kane J, Honigfeld G, Singer J, Meltzer HY, the Clozaril Collaborative Study Group (1988): Clozapine for the treatmentresistant schizophrenic: A double-blind comparison with chlorpromazine. Arch Gen Psychiatry 45:789-796

Lieberman JA, Johns CA, Kane JM, Rai K, Pisciotta AV, Saltz DL, Howard A (1988): Clozapine induced agranulocyto- 
sis: Non-cross reactivity with psychotropic drugs. J Clin Psychiatry 49:271-277

Losonczy MF, Davidson M, Davis KL (1987): The dopamine hypothesis of schizophrenia. In Meltzer HY (ed), Psychopharmacology: The third generation of progress, New York, Raven, pp 715-726

Malmberg ASA, Jackson DM, Eriksson A, Mohell N (1993): Unique binding characteristics of antipsychotic agents interacting with human dopamine $D_{2 A}, D_{2 B}$, and $D_{3}$ receptors. Mol Pharmacol 43:749-754

Matsubara S, Matsubara R, Kusumi I, Koyama T, Yamashita I (1993): Dopamine $D_{1}, D_{2}$ and serotonin 2 receptor occupation by typical and atypical antipsychotic drugs in vivo. J Pharmacol Exp Ther 265:498-508

Meltzer HY (1991): The mechanism of action of novel antipsychotic drugs. Schizophrenia Bull 17:263-287

Meltzer HY, Bastani B, Kwon B, Ramirez L, Burnett S, Shapre J (1989): A prospective study of clozapine in treatmentresistant schizophrenic patients. 1. Preliminary report. Psychopharmacology 99(suppl):S68-S72

Miller DD, Perry PJ, Cadoret RJ, Andreasen NC (1994): Clozapine's effect on negative symptoms in treatment-refractory schizophrenics. Compr Psychiat 35:8-15

Minabe Y, Ashby CR, Wang RY (1991): The effect of acute and chronic LY277349, a selective $5-\mathrm{HT}_{3}$ receptor antagonist, on the number of spontaneously active midbrain dopamine neurons. Eur J Pharmacol 209:151-156

Minabe Y, Ashby CR, Wang RY (1992): Effects produced by acute and chronic treatment with granisetron alone or in combination with haloperidol on midbrain dopamine neurons. Eur Neuropsychopharm 2:127-133

Moghaddam B, Bunney BS (1993): Depolarization inactivation of dopamine neurons. Terminal release characteristics. Synapse 14:195-200

Moore NA, Tye NC, Axton MS, Risius F(1992): The behavioral pharmacology of olanzapine, a novel "atypical" antipsychotic agent. J Pharmacol Exp Ther 262:545-551

Nordstrom A-L, Farde L, Wiesel F-A, Forslund K, Pauli S, Halldin C, Uppfeldt G (1993): Central D2-dopamine receptor occupancy in relation to antipsychotic drug effects: A double-blind PET study of schizophrenic patients. Biol Psychiatry 33:227-235

Palfreyman MG, Schmidt CJ, Sorensen SM, Dudley MW, Kehne JH, Moser P, Gittos MW, Carr AA (1993): Electrophysiological, biochemical and behavioral evidence for $5-\mathrm{HT}_{2}$ and $5-\mathrm{HT}_{3}$ mediated control of dopaminergic function. Psychopharmacology 112:S60-S67

Prisco S, Pessia M, Ceci A, Borsini F, Esposito E (1991): Chronic treatment with DAU 6215, a new 5- $\mathrm{HT}_{3}$ receptor antagonist, causes a selective decrease in the number of spontaneously active dopaminergic neurons in the rat ventral tegmental area. Eur J Pharmacol 214:13-19

Rasmussen K, Stockton ME, Czachura JF (1991a): The 5- $\mathrm{HT}_{3}$ receptor antagonist zatosetron decreases the number of spontaneously active A10 dopamine neurons. Eur J Pharmacol 205:113-116
Rasmussen K, Stockton ME, Czachura JF, Howbert JJ (1991b): Cholecystokinin (CCK) and schizophrenia: The selective CCK-B antagonist LY262691 decreases midbrain dopamine unit activity. Eur J Pharm 209:135-138

Roth BL Craigo SC, Choudhary MS, Uluer A, Monsma FJ, Shen Y, Meltzer HY, Sibley DR (1994): Binding of typical and atypical antipsychotic agents to 5-hydroxytryptamine-6 and 5-hydroxytryptamine-7 receptors. J Pharm Exp Ther 268:1403-1410

Seeman P (1992): Dopamine receptor sequences-therapeutic levels of neuroleptics occupy $\mathrm{D}_{2}$ receptors, clozapine occupies $\mathrm{D}_{4}$. Neuropsychopharmacology 7:261-284

Seeman P (1993): Schizophrenia as a brain disease: The dopamine receptor story. Arch Neurol 50:1093-1095

Seeman P, Chau-Wong M, Tedesco J, Wong K(1975): Brain receptors for antipsychotic drugs and dopamine: Direct binding assays. Proc Natl Acad Sci USA 72:4376-4380

Skarsfeldt T (1988a): Effect of chronic treatment with $\mathrm{SCH} 23390$ and haloperidol on spontaneous activity of dopamine neurons in substantia nigra pars compacta (SNc) and ventral tegmental area (VTA) in rats. Eur J Pharmacol 145:239-243

Skarsfeldt T (1988b). Differential effects after repeated treatment with haloperidol, clozapine, thioridazine and tefludazine on SNc and VTA dopamine neurons in rats. Life Sci 42:1037-1044

Skarsfeldt T (1992): Electrophysiological profile of the new atypical neuroleptic, sertindole, on midbrain dopamine neurons in rats: Acute and repeated treatment. Synapse 10:25-33

Skarsfeldt T (1993): Comparison of the effect of substituted benzamides on midbrain dopamine neurons after treatment of rats for 21 days. Eur J Pharmacol 240:269-275

Sorensen SM, Humphreys TM, Palfreyman MG(1989): Effect of acute and chronic MDL 73,147EF, a 5- $\mathrm{HT}_{3}$ receptor antagonist, on A9 and A10 dopamine neurons. Eur J Pharmacol 163:115-118

Stockmeier CA, DiCarlo JJ, Zhang Y, Thompson P, Meltzer HY (1993): Characterization of typical and atypical antipsychotic drugs based on in vivo occupancy of serotonin 2 and dopamine 2 receptors. J Pharmacol Exp Ther 266: 1374-1384

Wachtel SR, White FJ (1988): Electrophysiological effects of BMY14802, a new potential antipsychotic drug, on midbrain dopamine neurons in the rat: Acute and chronic studies. J Pharmacol Exp Ther 244:410-416

Watchtel SR, White FJ (1992): The effect of continuous and repeated administration of $\mathrm{D}_{1}$ dopamine receptor antagonist on midbrain dopamine neurons. Neurochem Int 20:129S-133S

Weinberger DR (1987): Implications of normal brain development for the pathogenesis of schizophrenia. Arch Gen Psych 44:660-669

White FJ, Wang RY (1983): Differential effects of classical and atypical antipsychotic drugs on A9 and A10 dopamine neurons. Science 221:1054-1057 